lettere for andre omkring ham å forstå hva som foregikk, hvorfor han handlet som han gjorde. Særlig ble det viktig for en kjent person. Boken forteller også hvordan det oppleves å ha en demenssykdom, hvordan det føles å glemme ting, ikke å kunne dra til jobben hver dag. Jan Henry setter klare ord på dette. Laila Lanes beskriver hvordan det oppleves å være pårørende til en som har demens: å bli irritert når vedkommende ikke husker og spør om den samme tingen mange ganger, å føle seg frustrert fordi man ikke kan være hjemme hele dagen.

Men det aller viktigste er det at forfatterne beskriver at livet forsetter som vanlig, at det må fortsette som vanlig. Det beskrives hvor viktig det er å skape gode opplevelser i hverdagen, reise, møte venner som man gjorde før sykdommen satte inn. Og hvor viktig det er at kjærligheten må fortsette å blomstre - og det gjør det for paret Lanes og Olsen. Beskrivelsen av kjærligheten mellom de to er både gripende og rørende. Jegpersonen sier at de på en måte er heldige, fordi de har fătt vite om sykdommen, fordi de nå vet at det haster å ha disse gode opplevelsene, det vil si: å skynde seg å elske.

Maria Lage Barca

Geriatrisk avdeling

Nasjonal kompetansesenter for aldring og helse Oslo universitetssykehus, Ullevål

\section{Uhyggelige historier}

Lunde A.

Noen iblant oss

96 s. Oslo: Aschehoug, 2009. Pris NOK 299 ISBN 978-82-03-19553-2

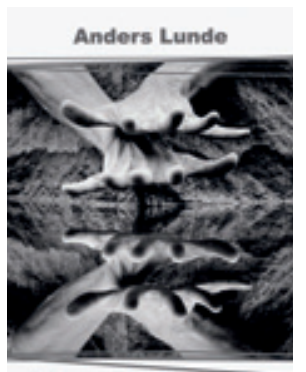

Noen iblant oss
Noen iblant oss er en novellesamling signert debutant Anders Lunde (f. 1976). De ti novellene byr på uhyggelige møter med livets og sinnets mørkere sider Lunde inviterer oss inn $i$ en litterær verden preget av antisosiale person-

ligheter, drapsfantasier og glidende overganger mellom drøm og virkelighet. Fortellerinstansen $\mathrm{i}$ tekstene er tidvis ustabil og upålitelig. Leserens fantasi mobiliseres, og dette bidrar til å vekke ubehagelige følelser. Lunde byr oss brokker av historier, og man blir sittende igjen med et ønske om å vite mer. Hva er bakgrunnen for hendelsene eller hovedpersonens fantasier? Tekstene gir oss sjelden noen bakenforliggende forklaring, og dette er et grep som bidrar til å gi en makaber effekt.
Novellene gir innblikk i virkeligheter og fenomener som ikke er helt fremmed for oss, og som man som lege blir konfrontert med i profesjonelle sammenhenger. Det er tidvis ubehagelig å lese tekstene, og som lege fristes man til å bruke psykiatriske begreper i forståelsen av de tankemønstre og den atferd som Lunde skildrer. Jeg får litterære assosiasjoner til verk av Edgar Allan Poe, Nikolaj Frobenius, Franz Kafka (Metamorfosen) og Charlotte Perkins Gilman (Det gule tapetet). Noen iblant oss er en brutal og sterk novellesamling som kan være nyttig å lese - men som også kan brukes som utgangspunkt for diskusjon i faglige sammenhenger.

Jan C. Frich

Avdeling for helseledelse og helseøkonomi Institutt for helse og samfunn

Universitetet i Oslo

\section{Vakker bok fra en overlevende}

Braadland JF

\section{Bare en overlevende}

Tekst og bilder i et post-tsunamisk perspektiv. 159 s, ill. Oslo: Tekstforlaget, 2009.

Pris NOK 349

ISBN 978-82-992312-3-7

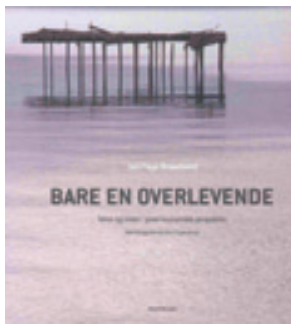

Målet for psykisk traumatiserte er ikke å glemme den overveldende påkjenningen, men å ikke måtte tenke på den. Forfatteren av denne vakre boken deler med leseren gjennom dikt, fotografier og egenberetninger sine opplevelser og minner som tsunamioverlevende. Tittelen «Bare en overlevende» henspiller på at han, fordi han ikke mistet nærstående, følte seg nedprioritert i forhold til overlevende som led tap og andre etterlatte.

I del 1 gir han en medrivende beskrivelse av de øvrige fire aspektene i katastrofepåkjenningen slik den artet seg for mange av de overlevende: dødsfaren, den fysiske skaden, de grufulle vitneopplevelsene og det vanskelige valget mellom egen overlevelse og å redde andre. Å forsøke å gi en sammenhengende beretning, et såkalt narrativ, av en overveldende påkjenning, har gjennom tidene sannsynligvis vært menneskehetens viktigste måte å overkomme traumatiske reaksjoner på. Å fortelle en personlig historie føyer sammen fragmenterte og splittende inntrykk og bidrar til at opplevelsen gjennom gjentakelser blir en erfaring. Dit har forfatteren ennå ikke nådd på det tidspunktet han skrev denne boken. Men skrivingen har sannsynligvis vært til hjelp for ham og kan bli det for andre.

I del 2 illustrerer Braadlands kone, Essi Frydenlund, også en overlevende, med fotografier hans dikteriske gjengivelse av katastrofepåkjenningen og hvordan den i ettertid lever i ham. Det er særlig disse sidene som kan leses med stort utbytte av andre som ble berørt eller rammet av katastrofen, som også gjør den til et supplement til faglitteratur. Bruken av kunst og diktning minner om at det finnes andre kilder til innsikter enn de strengt vitenskapelige.

Braadland gjengir i del 3 noen faktabeskrivelser av tsunamien og av posttraumatiske stressplager. Som enkelte andre tsunamirammede hevder han sterkt kritiske synspunkter på norske myndigheters forsøk på å hjelpe de rammede. I gjengivelsen av forskningsresultater fra forløpsundersøkelser av overlevende og etterlatte ville forfatteren vunnet på å oppdatere seg. Han ville da ha oppdaget at risikoen for psykiske helseskader har vist seg å være langt høyere hos tapsrammede overlevende enn hos dem som «bare» overlevde. Henimot hver annen person som både var i dødsfare og mistet en nærstående, led av en diagnostiserbar psykisk lidelse to år etter tsunamien. Likevel gjør forfatterens subjektivitet, hans åpenhet om hvordan tidligere livsproblemer ble påvirket av tsunamipåkjenningen, hans følsomme registreringsevne og introspektive kapasitet det lett å anbefale denne boken.

Lars Weisæth

Nasjonalt kunnskapssenter om vold og traumatisk stress

Universitetet i Oslo

\section{For mange pasienter og for få pleiere}

Panagiotaki E.

\section{Adjø Felicia}

Hjemmesykepleier i det rike Norge. 215 s.

Oslo: Spartacus forlag, 2009. Pris NOK 299 ISBN 978-82-430-0470-2

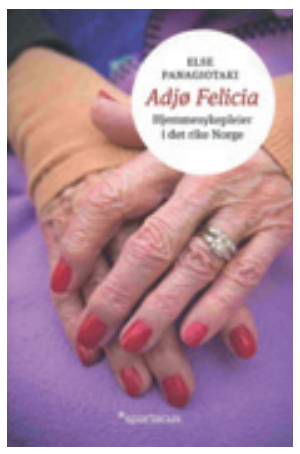

Forfatteren er norsk sykepleier, giftet seg med en greker og har bodd mange år på Kreta. Hun fikk lyst på et år i det gamle landet, som i mellomtiden var blitt rikt. Derfor tok hun seg jobb i hjemmesykepleien $\mathrm{i}$ bydel Frogner i Oslo, den velstående overklassebydelen i det gamle Oslo. Hun forteller om opplevelsene gjen- 
nom daglige notater som hun tok. Hun møter to kulturer.

Den ene er de gamle pasientene. De fleste av dem bor i store leiligheter som preges av fordums prakt, med fine gamle møbler, praktfulle malerier, tepper og kunst. De er ofte meget gamle og med mange og ofte alvorlige sykdommer og får inntil tre ganger daglig besøk fra hjemmesykepleien. Flesteparten er kvinner, og de har mistet sine nærmeste. To fellestrekk skiller seg ut: Det ene er at de er ensomme, for «alle deres er døde». De har slektninger, arvinger, men de er travelt opptatt med sitt. Derfor er ensomheten ofte overveldende og ødeleggende. Humoren har nok noen beholdt. En klappet seg på sitt hvite hode og sa om seksuallysten: «Det kan jo være fyr på peisen, selv om det er sne på taket!» Det andre trekket er at de ønsker å dø hjemme i sin egen seng, i fred og verdighet. De er livende redde for sykehus og sykehjem. Forfatteren opplever at ensomheten er det overveldende fellestrekket.

Den andre kulturen er hjemmesykepleien. Pleierne, bare kvinner, løper fra jobb til jobb. Listene deres er for lengst sprengt, men likevel kommer det stadige tillegg, fordi både de gamle og pleierne blir syke. Pleierne sykmelder seg fordi de er utslitt, selv om de vet at det går utover de andre, for de orker ikke mer. De løper etter stoppeklokkene og forsøker å klare de oppdragene administrasjonen har ført opp. Det er aldri tid til å sette seg ned, ta en kopp kaffe og snakke med de gamle. De må forholde seg til listene, de overfylte skittentøyskurvene og de stinkende søplebøttene.

Oppe i alt dette møter forfatteren Felicia, en gammel skrøpelig og kreftsyk dame på listen. Hun fortalte om den overveldende kjærligheten hun hadde opplevd med sin mann. De hadde bodd i flere år i Rom, og nå var mannen død. Hun bar på en siste drøm, og det var en tur til Rom for å gjenoppleve kjærligheten. Forfatteren ble med henne på en ukes tur til Roma, trillet henne omkring i rullestolen. Og Felicia gjenopplevde kjærligheten. Så dro de hjem, og neste morgen lå Felicia død i sengen sin etter å ha tatt en stor overdose sovemiddel. Forfatteren følte at Felicia hadde et lykkelig og takknemlig smil der hun lå.

Forfatteren skriver godt, ofte glitrende godt. Alle de små historiene om pasientene og pleierne er stor forfatterkunst. Mange i vårt samfunn ville ha glede av å lese denne boken og tenke over hvordan det er blitt og hva vi kan gjøre med det. Spesielt gjelder det selvfølgelig fastlegene og personalet i eldreomsorgen. Men aller mest gjelder det politikerne og byråkratene som har ansvaret for samfunnet og den veien vi går. Jeg håper boken får mange lesere.

\section{På dypt vann}

Jacobsen S

Passasjeren

317 s. Oslo: Aschehoug, 2009. Pris NOK 349 ISBN 978-82-03-21173-7

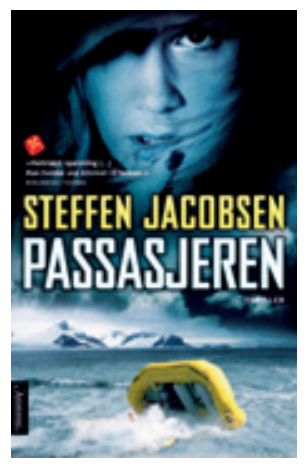

Den danske legen Steffen Jacobsen debuterte i 2008 (på norsk i 2009) som krimforfatter med boken Passasjeren. Handlingen er lagt til Sjælland og Bjørnøya, med avstikkere til Tromsø.

Vi møter den suksessrike forretningsmannen og milliardæren Axel Nobel og hans venn Jacob Nelleman. Sistnevnte drepes med pil og bue under en jakt på Nobels gods. Tilsynelatende en jaktulykke, men leseren vet nokså umiddelbart at dette er et mord.

Vi aner underliggende konflikter, og det fremgår at utspringet for disse er et forlis ved Bjørnøya et år tidligere, der Nobel og Nellemann var på seiltur sammen med den vakre unge kvinnen Anne Bjerke. Nobel og Nellemann reddet seg selv, men etterlot den skadede og døende Anne Bjerke. Anne ble aldri funnet. Etterforskningen avslører tidlig at Annes bror Jonas, en habil bueskytter, tilsynelatende har gjemt drapsvåpenet i sin egen garasje. At løsningen ikke er så enkel, forstår vi idet vi introduseres for en navnløs, ukjent person som hele tiden er på høyde med etterforskningen.

Deltidsarbeidende spillentusiast Robin Hansen er bokens politietterforsker. I krimlitteraturens brokete forsamling av bisarre etterforskere med outrert livsførsel og havarert privatliv, er han et sympatisk og oppfriskende bekjentskap. Hans overordnede Philipsen er langt mer karikert.

Den første halvdelen har en relativt slakk spenningskurve. Jacobsen er kunnskapsrik og har tendens til lange utredninger og blir i perioder noe doserende. Spesielt gjelder det seiling og båtlivets mange finesser, der en som aldri har satt sin fot $i$ en seilbåt fort blir hektet av og tar lesepause. Likevel, når det er sagt, begeistrer likevel Jacobsen. Han behersker det som tross alt er viktigst, nemlig språket. Han har grep om dialogene, snert i formuleringene, og hans evne til å tegne flerdimensjonale karakterer vitner om psykologisk innsikt. Dette til tross for at hans hang til bruk av similer, sammenlikninger, til tider blir noe påtrengende. I første del er også begrepet «som om» gjentatt påfallende hyppig, opptil tre ganger på en side. Jacobsen kommer likevel unna fordi han faktisk er både tørrvittig og uvanlig assosiasjonsrik.
Hvorvidt leseren tilfredsstilles, avhenger i stor grad av opprullingen. Her blir Jacobsen for langdryg. De lange naturbeskrivelsene og seilturens viderverdigheter blir for omstendelig og senker temperaturen $i$ avslutningen. Skurkens motiver for å drepe seks personer var for undertegnede heller ikke åpenbare.

Likevel vil jeg uten å nøle anbefale Passasjeren. Jeg vil utvilsomt også lese hans neste bok, i håp om at han da har karet seg i land og fortøyd båten.

Jorun Thørring Loennechen

Trondheim

\section{Når legen blir pasient}

Rygh 0.

\section{Undring fra rullestolen}

På jakt etter mestringskoden. 268 s, ill. Oslo: Kolofon forlag, 2009. Pris NOK 295 ISBN 978-82-300-0602-3

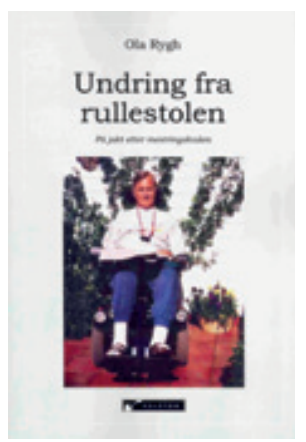

Kollega Ola Rygh var nettopp blitt pensjonist da han i 1995 styrtet på sykkelen, brakk nakken og ble rullestolavhengig tetraplegiker. Nå har han utgitt sine refleksjoner om det å være pasient i møtet med helsevesen og trygde-

system, i perspektivet fra et langt livs virke i norske sykehus. Men først og fremst er det en beretning om det å aldri gi opp, en hyllest til familien som kraftkilde og en kjærlighetserklæring til kona, som mer enn noen annen har gitt støtte og hjelp.

Vi følger forfatteren på veien gjennom sjokkfasen i starten, da det ble bråstopp for det fysisk aktive livet som han verdsatte så høyt, og videre gjennom en Pandoras kiste med besvær, komplikasjoner og møter med kolleger og institusjoner med varierende sjarm. Han er mange ganger langt nede, men hentes hver gang opp igjen av ukuelig livsvilje og støtte fra de nærmeste.

Boken er utgitt på Kolofon. Her gis forfatterne i liten grad forlagsfaglige råd $\mathrm{og}$ korrektur, og fremstillingen lider noe av det. Historien veksler mellom tanker rundt organiseringen av sykehusene før og nå, nyere biologiske erkjennelser og amatørfilosofiske refleksjoner. Dette har opplagt vært gode mestringsverktøy for forfatteren, men for leseren blir det springende og i blant litt banalt. Noe virker selvsagt for en leser fra helsevesenet, men samtidig faginternt for den som står utenfor. Bokens sterkeste side blir derfor selve beretningen. 